\begin{tabular}{r|l|l|l}
$\begin{array}{c}\text { Case Reports in } \\
\text { Gastroenterology }\end{array}$ & $\begin{array}{l}\text { Case Rep Gastroenterol 2010;4:351-355 } \\
\text { DOl: 10.1159/000320682 }\end{array}$ & $\begin{array}{l}\text { Published online: } \\
\text { September 15, 2010 }\end{array}$ & $\begin{array}{l}\text { O 2010 S. Karger AG, Basel } \\
\text { ISSN 1662-0631 } \\
\text { www.karger.com/crg }\end{array}$ \\
\hline
\end{tabular}

\title{
Rectal Carcinoma with Heterotopic Bone: Report of a Case
}

\author{
Yuichi Nagao $^{\mathrm{a}}$ Shohei Shimajiri $^{\mathrm{b}}$ Takefumi Katsuki ${ }^{\mathrm{a}}$ \\ Yoshifumi Nakayama ${ }^{a}$ Koji Yamaguchia

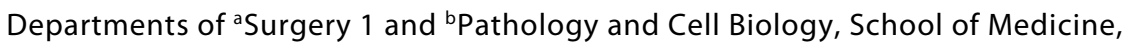 \\ University of Occupational and Environmental Health, Kitakyushu, Japan
}

\section{Key Words}

Rectum · Adenocarcinoma $\cdot$ Osseous metaplasia

\begin{abstract}
Heterotopic bone is rarely present in malignant tumors of the gastrointestinal tract. We herein report a case of rectal adenocarcinoma with heterotopic bone. A 46-year-old Japanese male presented to our hospital with abdominal distension and constipation. Colonoscopic examination showed an ulcerated polypoid tumor of the rectum which nearly obstructed the rectal lumen. Abdominal computed tomography showed a tumor of the rectum with calcified deposits. Low anterior resection with lateral lymph node dissection was performed under the tentative diagnosis of rectal cancer. Histological examination of the resected specimen showed mucinous carcinoma of the rectum with heterotopic bone. One of the metastatic lymph nodes dissected also showed heterotopic bone. In the present report, we describe this rare tumor and briefly review the pertinent literature regarding rectal cancer with heterotopic bone.
\end{abstract}

\section{Introduction}

Heterotopic bone is very rarely seen in malignant conditions of the gastrointestinal tract. Dukes [1] first reported that gastrointestinal tumors with heterotopic ossification were low-grade malignancies with no tendency to spread by the venous or lymphatic systems. We herein present a case of heterotopic bone present in rectal cancer and in one of the metastatic lymph nodes.

\section{Case Report}

A 46-year-old male went to a neighboring hospital with a 1-month history of abdominal distension and constipation. Digital examination of the rectum revealed a palpable tumor. Colonoscopic 
examination showed an ulcerated polypoid tumor almost obstructing the rectal lumen. Endoscopic biopsy of the rectal tumor led to classification of the tumor as adenocarcinoma. The patient was referred to us for further examination and treatment. Laboratory data, including tumor markers (carcinoembryonic antigen and carbohydrate antigen 19-9) were within normal limits. Abdominal computed tomography showed a rectal tumor with calcified deposits, without any sign of metastatic lymph nodes (fig. 1). Therefore, a low anterior resection with lateral lymph node dissection was performed under the tentative diagnosis of rectal cancer with calcification.

The resected specimen showed a large polypoid tumor $(9 \times 7 \mathrm{~cm})$ with superficial ulceration situated $3 \mathrm{~cm}$ from the distal resection margin and almost encircling the rectum (fig. 2). Histologically, the tumor was a mucinous carcinoma extending through the muscularis propria and invading the adjacent perirectal adipose tissue with lymphatic permeation. Abundant fibrovascular stroma was present, and well-formed bony trabeculae were noted mainly in the stroma (fig. $3 \mathrm{a}$ ). These consisted of irregular islands of mineralized osteoid bone rimmed by a layer of scattered osteoblasts. No necrosis was seen within the tumor. The surgical margins were free of tumor tissue. Eleven of the 20 lymph nodes dissected had metastatic carcinoma, and one of them showed heterotopic bone (fig. 3b). The patient's postoperative course was uneventful, and he was doing well with no signs of recurrence 3 months after the operation.

\section{Discussion}

Rectal cancer is a common disease, but coincidental heterotopic bone is rarely seen. Heterotopic bone has been reported in primary and metastatic gastrointestinal tumors including carcinoma of the stomach, appendix and colorectum. It has also been observed in adenoma of the rectum and carcinoid tumors of the stomach [1-4]. In the landmark paper, Dukes reported that the incidence of ossification of rectal cancer was less than $0.4 \%$ [1]. To the best of our knowledge, there have been only ten cases of heterotopic bone in rectal adenocarcinoma reported in the English language literature [1, 2, 4-11]. Unlike the present case, these cases showed no heterotopic bone in the metastatic lymph nodes.

Some clinicopathologic features of rectal adenocarcinoma with heterotopic bone have been reported. Dukes reported the following features concerning rectal carcinoma with heterotopic bone: (1) long duration of symptoms indicating slow growth of the tumor; (2) histologically low-grade malignancy with no tendency to spread through the veins or lymphatics; (3) presence of a necrotic area within the tumor [1]. Although none have been previously reported for rectal cancer, several cases of heterotopic ossification in local recurrences or in metastatic sites have been reported in addition to heterotopic ossification in the primary sites $[1,4,5]$. In our case, eleven of the 20 lymph nodes dissected showed metastatic deposits, and one of them had heterotopic bone.

The mechanism of heterotopic bone formation within gastrointestinal adenocarcinoma is not completely understood. The most plausible explanation for heterotopic ossification in tumors of epithelial origin is a metaplastic process of the stromal mesenchymal cells, wherein they transform into osteoblasts. Supporting this theory, heterotopic bone is more likely to be found in necrotic tumors, the mucin pool, and the tumor stroma [12]. In addition, a number of other theories exist. For example, Randall et al. [3] suggested that metastatic colonic carcinoma can promote heterotopic ossification, and that alkaline phosphatase is intimately associated with bone formation under these pathological conditions, because immunostaining for alkaline phosphatase is seen not only in osteoblast-like cells, but also in the atypical membrane of the cancer cells next to areas of the bone. Rosenbaum et al. [13] suggested that large quantities of gamma-carboxyglutamic acid may be associated with the calcification of bone matrix in a 


\begin{tabular}{r|l|l|l}
$\begin{array}{r}\text { Case Reports in } \\
\text { Gastruanterology }\end{array}$ & $\begin{array}{l}\text { Case Rep Gastroenterol 2010;4:351-355 } \\
\text { DOl: 10.1159/000320682 }\end{array}$ & $\begin{array}{l}\text { Published online: } \\
\text { September 15, 2010 }\end{array}$ & $\begin{array}{l}\text { O 2010 S. Karger AG, Basel } \\
\text { ISSN 1662-0631 } \\
\text { www.karger.com/crg }\end{array}$ \\
\hline
\end{tabular}

patient with ossifying skeletal muscle metastases. Rhone and Horowitz [14] suggested that heterotopic ossification is metaplasia of fibroblasts induced by diffusible factors released from rapidly dividing epithelial cells of the tumor or by direct contact with epithelial cells of the tumor. Imai et al. [15] reported that bone morphogenetic protein produced by gastrointestinal tract glandular tumor cells might play an important role in heterotopic ossification. In the present case, no necrosis was evident, but the histological type was mucinous adecarcinoma.

Heterotopic bone is rarely present in the gastrointestinal tract, including benign and malignant epithelial tumors. Further studies are therefore necessary to determine the factors that play a role in the development of heterotopic bone formation in gastrointestinal tumors, and to confirm the impact of this bone formation on patient outcome.

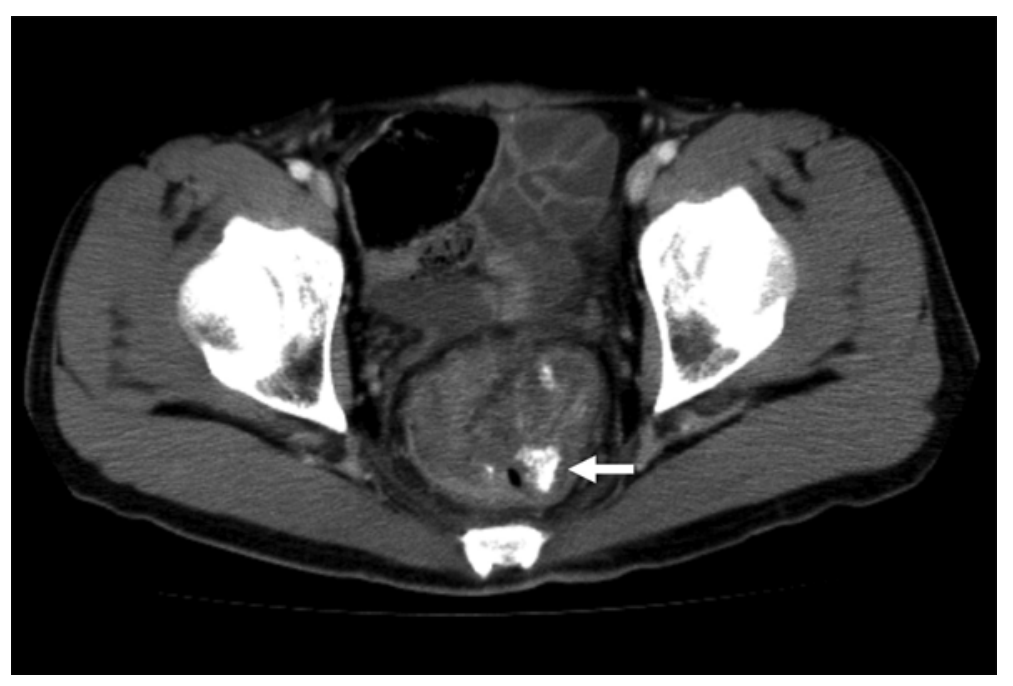

Fig. 1. Abdominal computed tomography showed a tumor in the rectum with calcified deposits (arrow), without any sign of metastatic lymph nodes. 


\begin{tabular}{r|l|l|l}
$\begin{array}{c}\text { Case Reports in } \\
\text { Gastruenterology }\end{array}$ & $\begin{array}{l}\text { Case Rep Gastroenterol 2010;4:351-355 } \\
\text { DOI: 10.1159/000320682 }\end{array}$ & $\begin{array}{l}\text { Published online: } \\
\text { September 15, 2010 }\end{array}$ & $\begin{array}{l}\text { O 2010 S. Karger AG, Basel } \\
\text { ISN 162-20631 } \\
\text { www.karger.com/crg }\end{array}$ \\
\hline
\end{tabular}

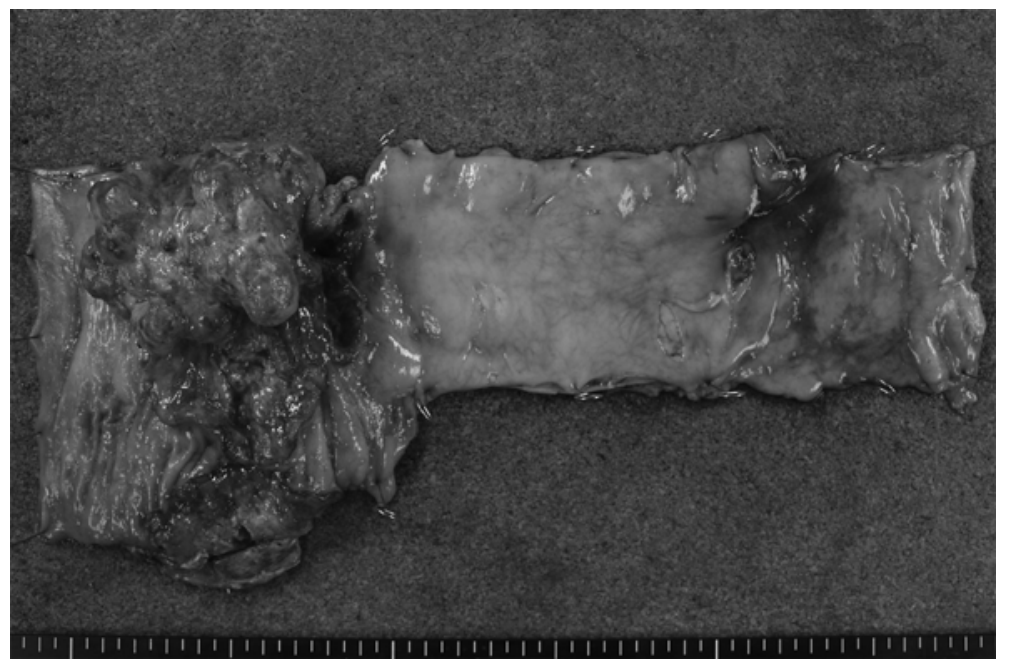

Fig. 2. The resected specimen contained a large polypoid tumor $(9 \times 7 \mathrm{~cm})$ with superficial ulceration.
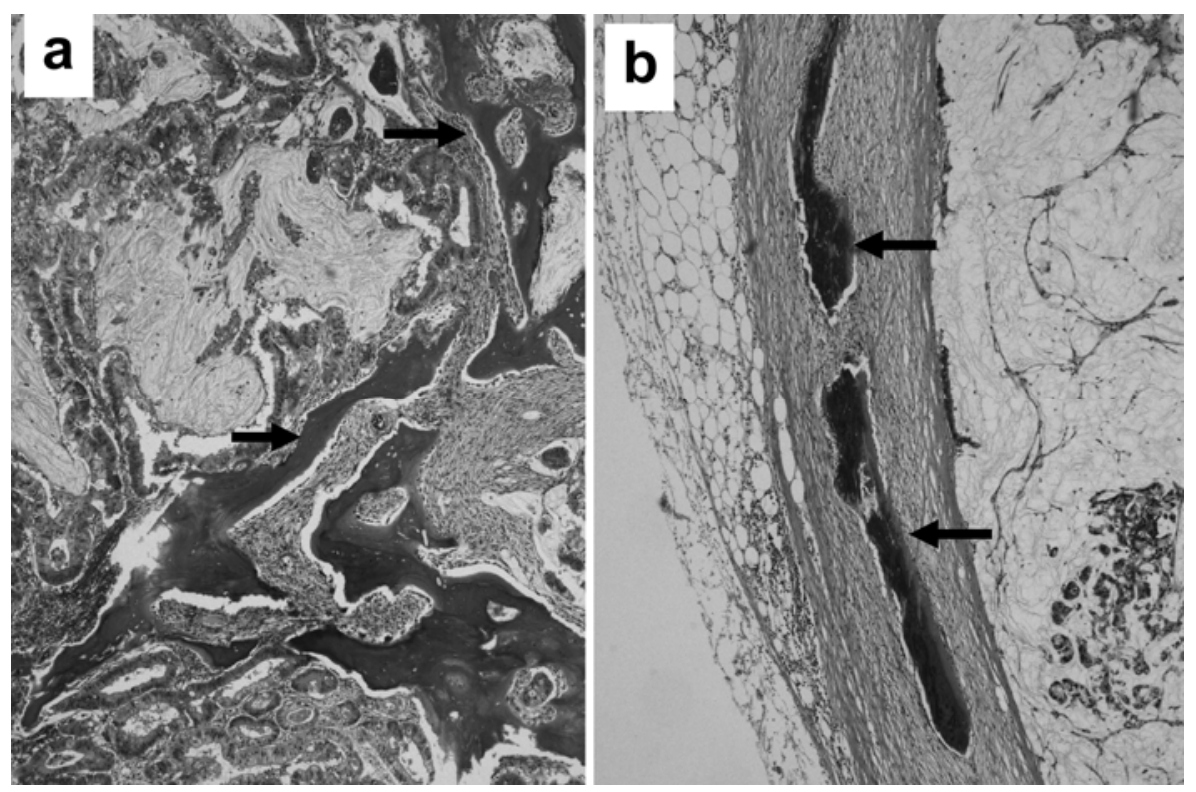

Fig. 3. a Histologically, the tumor was a mucinous adenocarcinoma with well-formed bony trabeculae in the stroma (arrows). Abundant fibrovascular stroma was present. b Eleven of the 20 lymph nodes dissected had metastatic carcinoma, and one of them showed heterotopic bone (arrows).

\section{References}

1 Dukes CE: Ossification in rectal cancer. Proc R Soc Med 1939;32:1489-1494.

2 Ansari MQ, Sachs IL, Max E, Alpert LC: Heterotopic bone formation in rectal carcinoma: case report and literature review. Dig Dis Sci 1992;37:1624-1629.

3 Randall JC, Morris DC, Tomita T, Clarke Anderson H: Heterotopic ossification: a case report and immunohistochemical observation. Hum Pathol 1989;20:86-88. 
4 Van Patter HT, Whittick JW: Heterotopic ossification in intestinal neoplasms. Am J Pathol 1955;31:73-91.

-5 Senturia HR, Schechter SE, Hulbert B: Heterotopic ossification in an area of metastasis from rectal carcinoma. AJR Am J Roentgenol 1948;60:507-510.

6 Urbanke A: Heterotopic ossification in rectal carcinoma. Gastroenterologia 1962;98:48-53.

7 Haque S, Eisen RN, West AB: Heterotopic bone formation in the gastrointestinal tract. Arch Pathol Lab Med 1996;120:666-670.

8 Kypson AP, Morphew E, Jones R, Gottfried MR, Seigler HF: Heterotopic ossification in rectal cancer: rare finding with a novel proposed mechanism. J Surg Oncol 2003;82:132-136.

9 Matsumoto T, Masuda T, Inomata M, et al: Heterotopic ossification of rectal adenocarcinoma: report of a case. Surg Today 2004;34:167-169.

10 Szumito J, Chroscicki A, Swatek J, Korobowicz E: Rectal adecnocarcinoma with osseous metaplasia. Pol J Pathol 2004;55:39-40.

11 Pai SA, Bhasin SD, Krishnamurthy SC: Heterotopic ossification in adenocarcinoma of the rectum. Indian J Pathol Microbiol 1993;36:304-307.

12 Lauwers GY, Wahl SJ, Richard GK: Osseous metaplasia in colonic adenocarcinoma (letter). Am J Gastroenterol 1991;86:382.

13 Rosenbaum LH, Nicholas JJ, Slasky BS, Obley DL, Ellis LD: Malignant myositis ossificans: occult gastric carcinoma presenting as an acute rheumatic disorder. Ann Rheum Dis 1942;43:95-97.

14 Rhone DP, Horowitz RN: Heterotopic ossification in the pulmonary metastases of gastric adenocarcinoma. Cancer 1976;38:1773-1780.

15 Imai N, Iwai A, Hatakeyama S, et al: Expression of bone morphogenetic proteins in colon carcinoma with heterotopic ossification. Pathol Int 2001;51:643-648. 